\title{
High rate of autonomic neuropathy in Cornelia de Lange Syndrome
}

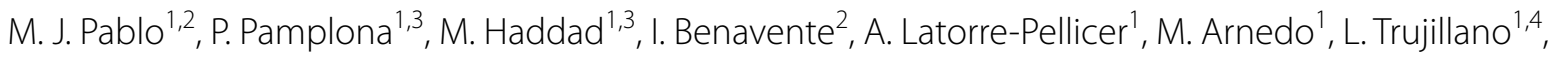 \\ G. Bueno-Lozano ${ }^{1,5}$, L. M. Kerr ${ }^{6}$, S. A. Huisman ${ }^{7,8}$, F. J. Kaiser ${ }^{9}$, F. Ramos ${ }^{1,4}$, A. D. Kline ${ }^{10}$, J. Pie ${ }^{1 *}$ (D) and B. Puisac ${ }^{1 *}$
}

\begin{abstract}
Background: Cornelia de Lange Syndrome $(C d L S)$ is a rare congenital disorder characterized by typical facial features, growth failure, limb abnormalities, and gastroesophageal dysfunction that may be caused by mutations in several genes that disrupt gene regulation early in development. Symptoms in individuals with CdLS suggest that the peripheral nervous system (PNS) is involved, yet there is little direct evidence.
\end{abstract}

Method: Somatic nervous system was evaluated by conventional motor and sensory nerve conduction studies and autonomic nervous system by heart rate variability, sympathetic skin response and sudomotor testing. CdLS Clinical Score and genetic studies were also obtained.

Results: Sympathetic skin response and sudomotor test were pathological in 35\% and 34\% of the individuals with $\mathrm{CdLS}$, respectively. Nevertheless, normal values in large fiber nerve function studies.

Conclusions: Autonomic nervous system (ANS) dysfunction is found in many individuals with Cornelia de Lange Syndrome, and could be related to premature aging.

Keywords: Cornelia de Lange Syndrome, CdLS, Small fiber nerve, Peripheral neuropathy, Autonomic neuropathy, Sudomotor test, Sweat gland density, NIPBL gene

\section{Background}

Cornelia de Lange Syndrome (CdLS) is a genetic disease due to spontaneous mutations in genes of the cohesin protein complex, mainly $N I P B L$, in $70 \%$ of the cases [1-4] and SMC1A, SMC3, RAD21, BRD4, HDAC8, ANKRD11 and MAU2 [5-9]. Manifestations of the syndrome differ with mutated gene type, with variants in NIPBL often associated with more severe clinical phenotype. The syndrome is characterized by typical facial features, growth failure, limb abnormalities and the involvement of many organs and systems including the central nervous system. Sweating abnormalities, abnormal reactions to cold and

\footnotetext{
*Correspondence: juanpie@unizar.es; puisac@unizar.es

${ }^{1}$ Unit of Clinical Genetics and Functional Genomics, Department

of Pharmacology-Physiology, School of Medicine, University of Zaragoza, CIBERER-GCV02 and IIS-Aragon, Zaragoza, Spain

Full list of author information is available at the end of the article
}

heat, and severe gastrointestinal reflux are also prevalent and suggest a compromised peripheral nervous system [1]. More than $80 \%$ of individuals with CdLS have some autonomic nervous system dysfunction, while $26 \%$ of those have moderate to severe dysfunction as measured by the Compass-31 questionnaire, a validated survey tool for autonomic dysfunction [10]. The aim of this study was to get new insights into neuronal dysfunction in CdLS by analyzing large and small fiber nerves with different techniques.

\section{Patients and methods}

All the peripheral nervous system studies, except the sudomotor test, were made in a group of 20 individuals with CdLS (7 male, 13 female, aged 3-37 years). In the sudomotor test the population was broadened to 47 individuals with CdLS (18 male, 29 female, aged 1.5-42 years) and 50 slightly older healthy controls (18 male, 32 female, original author(s) and the source, provide a link to the Creative Commons licence, and indicate if changes were made. The images or other third party material in this article are included in the article's Creative Commons licence, unless indicated otherwise in a credit line to the material. If material is not included in the article's Creative Commons licence and your intended use is not permitted by statutory regulation or exceeds the permitted use, you will need to obtain permission directly from the copyright holder. To view a copy of this licence, visit http://creativecommons.org/licenses/by/4.0/. The Creative Commons Public Domain Dedication waiver (http://creativeco mmons.org/publicdomain/zero/1.0/) applies to the data made available in this article, unless otherwise stated in a credit line to the data. 
aged 7-48 years). All of the individuals with CdLS and controls were Caucasian, except 3 Latino and 1 Middle East subjects in the CdLS group. The protocol study was approved by the Ethics Committee of Clinical Research from the Government of Aragón (CEICA;PI16/225). All the individuals with CdLS and controls gave informed consent for their participation.

To evaluate the somatic peripheral nervous system, conventional motor and sensory nerve conduction studies [11-15] were carried out in upper and lower limbs (large fiber nerves).

The autonomic nervous system (small fibre nerves) was studied by means of heart rate variability at rest, sympathetic skin response and sudomotor test. Heart rate variability (HRV) at rest was evaluated recording the heart rate for $5 \mathrm{~min}$ [16]. Sympathetic skin response (SSR) was studied with electric stimuli over the Median and Posterior Tibial nerves, recording the responses over the palm of both hands (Median) and the sole of both feet (Tibial) $[17,18]$. Nerve conduction studies, HRV and SSR were performed by the same group of neurophysiologists with a 5-channel Natus ${ }^{\circledR}$ Electromyography equipment. The sudomotor test, which gives the number of functioning sweat glands per $\mathrm{cm}^{2}$ (sweat gland density, SGD) was obtained on a silicone mold after pilocarpine iontophoresis stimulation over the foot dorsum [19].

Genetic studies were realized by standard Sanger sequencing and Next Generation Sequencing (NGS) panels. Clinical severity score according to the first international consensus statement [1] was also studied (Table 1). Statistical studies were achieved with the SPSS program version 25 .

\section{Results}

Conventional motor and sensory nerve conduction studies (large fiber nerves) were normal in all 20 individuals with CdLS analyzed (Additional file 1: Tables 1-3). The study of the autonomic nervous system (small fiber nerves) in HRV at rest was normal as well (Table 2). Nevertheless, SSR revealed mild alterations in lower limbs in 7 of the 20 individuals, with asymmetrical responses (Table 2, Fig. 1). Sudomotor tests evinced reduced SGD in 16 of the 47 individuals with CdLS regarding the control group by decades of life (Table 3 ). The regression analysis showed that, in spite of dispersion, there were two different populations, with statistically significant differences between the control group and individuals with CdLS $(p<0.05$ and $p<0.01)$ (Fig. 2). The linear regression showed that the slope of the SGD reduction by age is much more pronounced in individuals with CdLS than in controls (Fig. 2). Independence samples $\mathrm{T}$ test showed the results of the mean differences of the sweat gland density (SGD) by age group, with reduction in the
SGD more evident in the individuals with variants in NIPBL than in the controls $(\mathrm{p}<0.01)$. These differences were found in the whole NIPBL group as in all the decades of life, except the first one (Fig. 2, Table 4).

Genetic studies of the 47 individuals with CdLS revealed 31 with variants in NIPBL, 4 in $S M C 1 A, 2$ in RAD21, 2 in $H D A C 8$ and 1 in $S M C 3$ and negative in 7 individuals (Table 3). In Table 3 there are the CdLS Clinical Scores [1]. No relationship between clinical score or gastroesophageal reflux disease (GERD) and findings of the sudomotor test was found. In Additional file 1: Table 4 is shown the SGD in the control group by decades of life.

\section{Discussion}

Though the clinical manifestations of CdLS suggest that the peripheral nervous system is affected, large fiber nerve studies (conventional motor and sensory nerve conduction studies) are within normal limits. However, we have shown evidence, for the first time, for autonomic nervous system dysfunction in individuals with CdLS.

The sympathetic skin response reveals asymmetrical pathological responses in lower limbs in 7 of the 20 individuals (35\%), with one of them affected in upper limbs as well. This could be considered a malformative manifestation of the syndrome. However, it is remarkable that the asymmetry is more frequent in lower than in upper limbs, which are often more affected [1-4]. This asymmetry does not seem to be related to GERD or the Clinical Severity Score (CSS), yet all the individuals had mutations in the NIPBL gene (Table 2).

Sudomotor testing shows a reduction in the sweat gland density (SGD) in 16 of 47 (34\%) of the analyzed individuals with CdLS. These data are further supported by a reduction of the number of sweat droplets imprinted on the silicone after pilocarpine iontophoresis as indirect evidence of decreased postganglionic sudomotor nerve fibers, compared to an unaffected population. Though sweat gland density decreases physiologically with aging, individuals with CdLS show a reduction much greater than should be expected by their age. This decrease is evident from the second decade of life, and is more pronounced at older ages (Table 3, Fig. 2). All of this seems to strengthen the hypothesis that these patients have premature aging. Nevertheless, no relationships were found between SGD reduction and clinical score or GERD.

The reduction in the SGD is evident in individuals with mutations in NIPBL (Tables 3, 4), and seems to be similar in individuals with variants in $S M C 1 A$ (3 of the 4 individuals with mutations in $S M C 1 A$ had SGD reduction). However, individuals with variants in $H D A C 8$ and $R A D$ 21 are in the first decade of life, so it is early to make an assessment. Surprisingly, there is a high value of sweat 


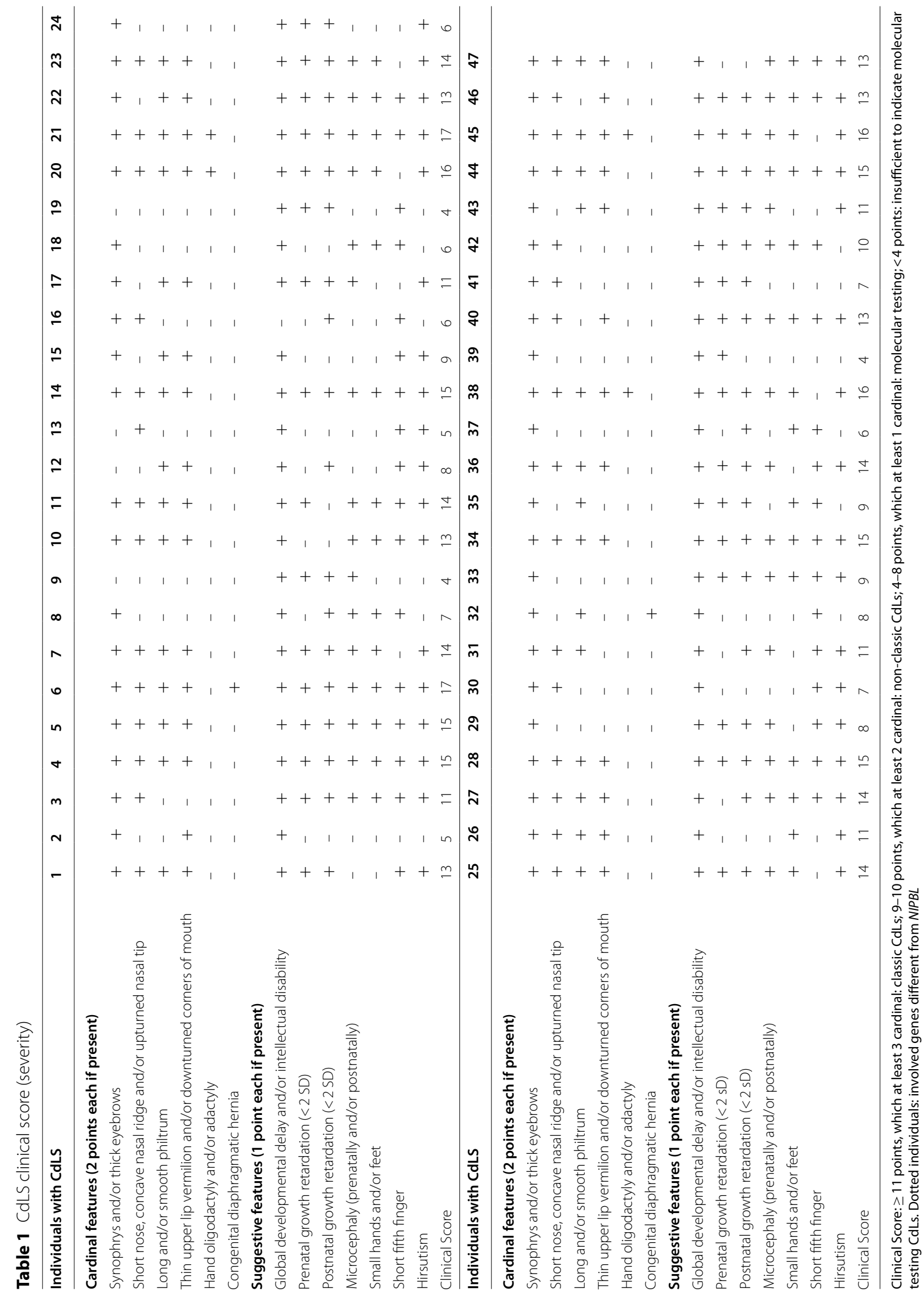


Table 2 Sympathetic skin response and heart rate variability in CdLS

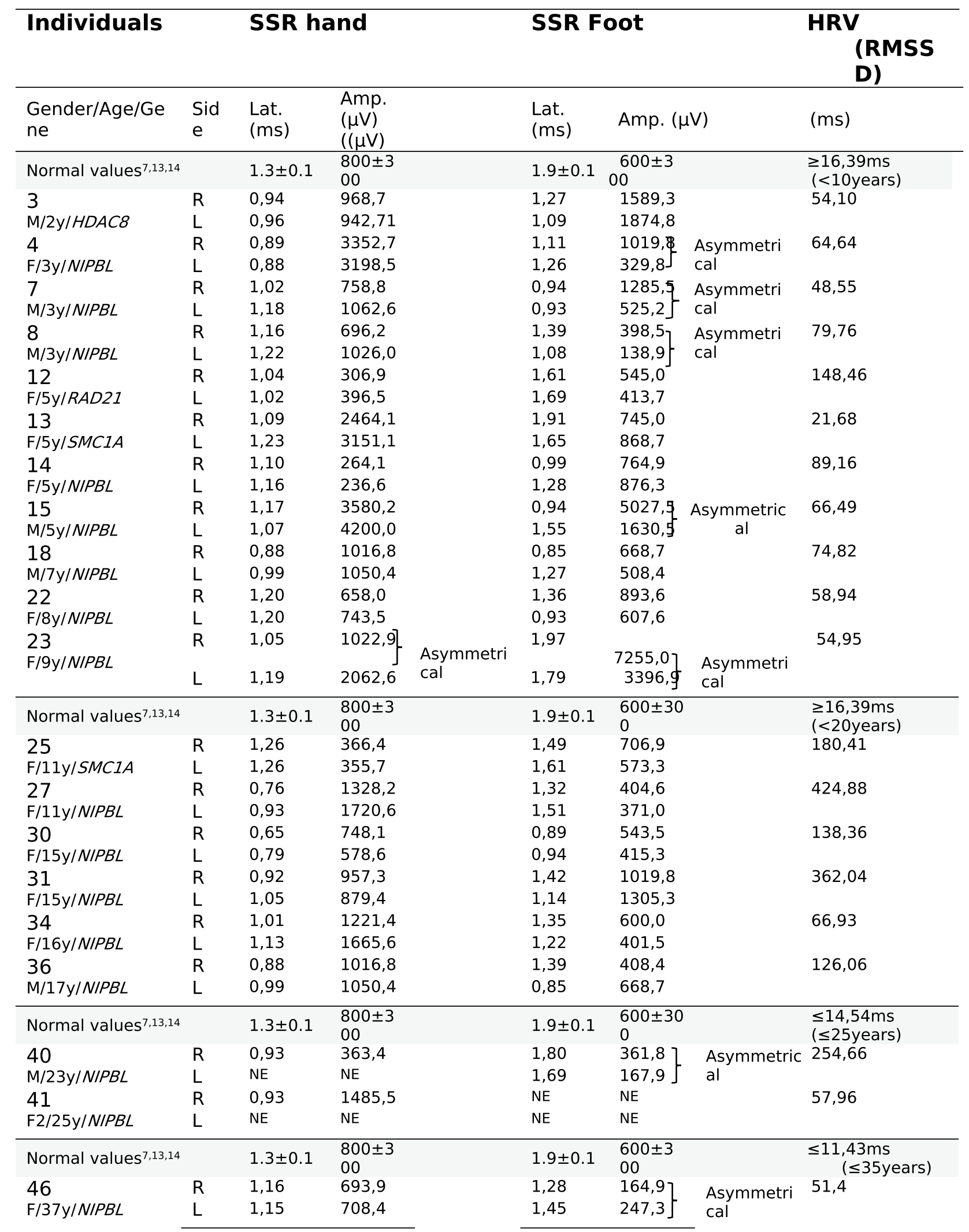


Table 2 (continued)

SSR Sympathetic Skin Response; HRV Heart Rate Variability; RMSSD Root Mean Square of Successive Differences. Lat latency; Amp Amplitude; ms milliseconds; $\mu V$ microvolts; NE Not examined. P40 left arm not studied. P41 only cooperated for the SSR study in one hand. Asymmetrical: Used to indicate side-to-side differences in amplitude and/or morphology in the Sympathetic Skin Response (SSR) in both upper or lower limbs

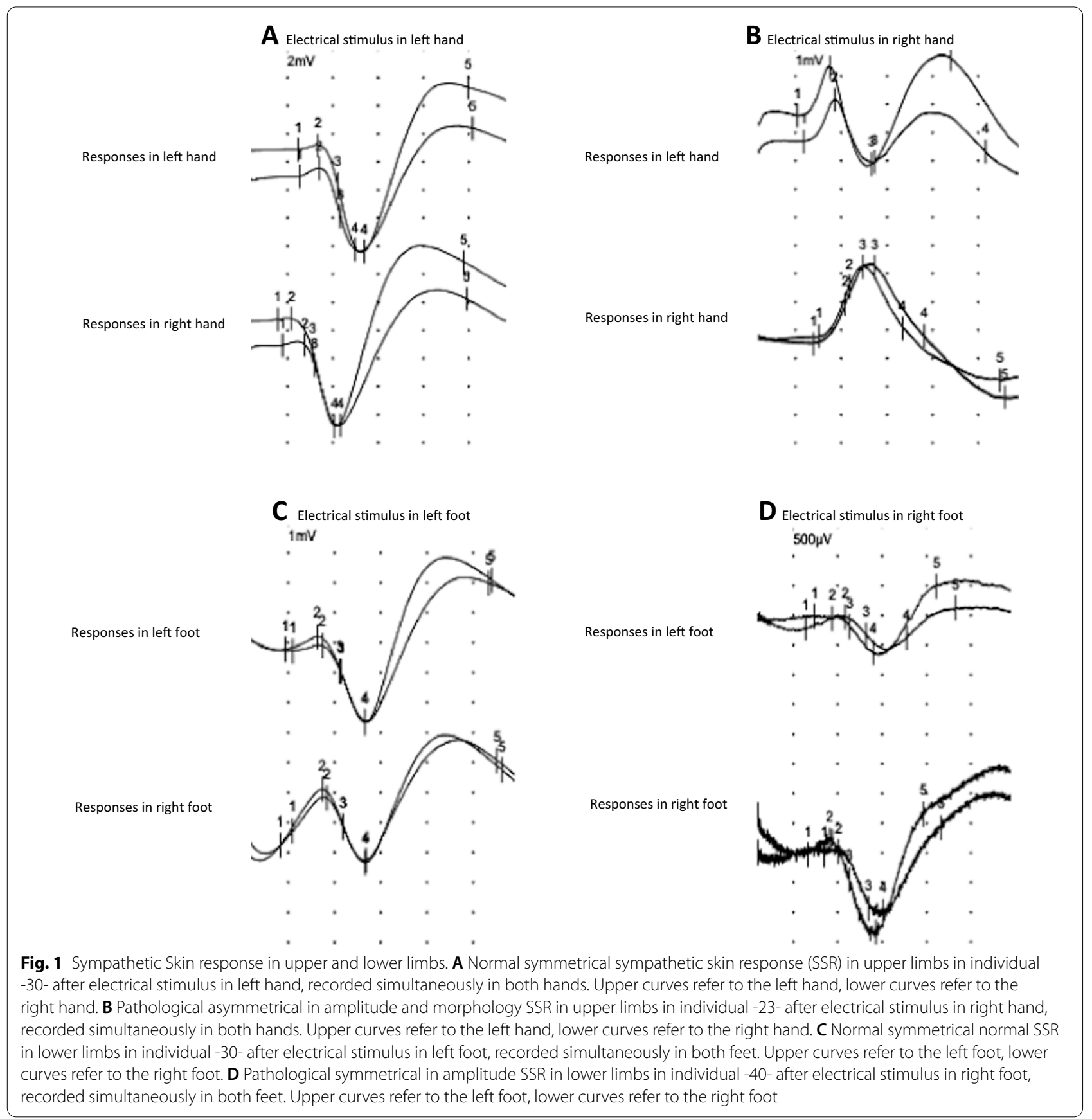

gland density in the only individual with an SMC3 mutation, who is 39 years old. Regarding the ethnic distribution, only 4 individuals in the NIPBL group and none in the control group were not Caucasian, and all of them had normal values in SGD, though they were in the first decade of life. In the group of NIPBL, there is a repeated 
Table 3 Genetics, clinical score and sweat gland density (SGD) in individuals with CdLS in different decades of life.

\begin{tabular}{|c|c|c|c|c|c|c|c|c|c|c|c|}
\hline $\begin{array}{l}\text { INDIVIDU } \\
\text { ALS }\end{array}$ & $\begin{array}{l}\text { Control } \\
\text { group }\end{array}$ & 1 & 2 & 3 & 4 & 5 & 6 & 7 & 8 & 9 & 10 \\
\hline $\begin{array}{l}\text { Age (years) } \\
\text { Gender } \\
\text { Gene } \\
\text { Mutation }\end{array}$ & $\begin{array}{l}\text { 1-10 years } \\
\text { Mean of } 13 \\
\text { individuals }\end{array}$ & $\begin{array}{c}1.5 \\
\mathrm{~F} \\
?\end{array}$ & $\begin{array}{c}1.5 \\
\text { M } \\
S M C I A\end{array}$ & $\begin{array}{c}\stackrel{2}{M} \\
H D C B \\
c .305 G>A \\
p . C y s 102 T\end{array}$ & $\begin{array}{c}3 \\
F \\
\text { NIFBL } \\
\text { c.6549.6552delli } \\
\text { TCA }\end{array}$ & $\begin{array}{l}3 \\
\mathrm{M}\end{array}$ & $\begin{array}{c}3 \\
M \\
N P B L\end{array}$ & $\begin{array}{c}3 \\
M \\
N \\
N / P B L \\
\text { c.3021delA } \\
\text { (mosaicism) }\end{array}$ & $\begin{array}{c}3 \\
M \\
N / P B L \\
\text { c.5329-15A>G } \\
\text { c.iie1777_Arg1809d }\end{array}$ & $\begin{array}{l}\begin{array}{l}4 \\
F \\
?\end{array} \\
\end{array}$ & $\begin{array}{l}4 \\
\text { F } \\
?\end{array}$ \\
\hline \multirow{2}{*}{$\begin{array}{l}\text { Clinical } \\
\text { Score } \\
\text { GERD } \\
\text { SGD }\end{array}$} & & 13 & 5 & $\begin{array}{l}\mathrm{yr} \\
11\end{array}$ & $\begin{array}{l}\text { p.His218GInfs*13 } \\
15\end{array}$ & 15 & 17 & 14 & $\begin{array}{l}\text { el } \\
7\end{array}$ & 4 & 13 \\
\hline & $\underset{5}{236.76 \pm 33.4}$ & $\begin{array}{l}++ \\
229\end{array}$ & 159 & 300 & $\begin{array}{c}+ \\
287\end{array}$ & 322 & $\begin{array}{l}+++ \\
322\end{array}$ & $\begin{array}{c}+ \\
200\end{array}$ & $\begin{array}{c}+ \\
110\end{array}$ & $\begin{array}{l}++ \\
286\end{array}$ & $\begin{array}{l}++ \\
254\end{array}$ \\
\hline $\begin{array}{l}\text { INDIVIDU } \\
\text { ALS }\end{array}$ & 11 & 12 & 13 & 14 & 15 & 16 & 17 & 18 & 19 & 20 & 21 \\
\hline $\begin{array}{l}\text { Age (years) } \\
\text { Gender } \\
\text { Gene } \\
\text { Mutation }\end{array}$ & $\begin{array}{c}\begin{array}{c}4 \\
F \\
H D A C B\end{array} \\
H A\end{array}$ & $\begin{array}{c}5 \\
F \\
\text { FAD21 } \\
\text { C.1382C>T } \\
\text { p.Pro395Le } \\
u\end{array}$ & $\begin{array}{c}5 \\
\text { F } \\
\text { SMIA } \\
\text { NM_006306:C2096 } \\
>T\end{array}$ & $\begin{array}{c}5 \\
M \\
N I P B L\end{array}$ & $\begin{array}{c}5 \\
F \\
N / P B L \\
\text { C7736C>T } \\
\text { p.Ala2579Val }\end{array}$ & $\begin{array}{l}6 \\
F \\
N I P B L\end{array}$ & $\begin{array}{c}6 \\
M \\
N I P B L\end{array}$ & $\begin{array}{c}7 \\
M \\
\text { NPBL } \\
\text { c.c329.15A>G } \\
\text { c.iie1777.AAg } \\
\text { 9del }\end{array}$ & 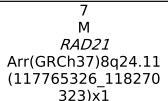 & $\begin{array}{l}7 \\
F \\
\text { NIPBL }\end{array}$ & $\begin{array}{c}7 \\
F \\
N I P B L\end{array}$ \\
\hline \multirow{2}{*}{$\begin{array}{l}\text { Clinical } \\
\text { Score } \\
\text { GERD } \\
\text { SGD }\end{array}$} & 14 & $\begin{array}{l}\mathrm{u} \\
8\end{array}$ & 5 & 15 & 9 & 6 & 11 & $\begin{array}{c}9 \text { del } \\
6\end{array}$ & $\begin{array}{c}323) 1 \\
4\end{array}$ & 16 & 17 \\
\hline & $\begin{array}{r}++ \\
235 \\
\end{array}$ & $\begin{array}{c}+ \\
307 \\
\end{array}$ & $\begin{array}{c}+ \\
243 \\
\end{array}$ & $\stackrel{+}{218}$ & 91 & 339 & $\begin{array}{l}++ \\
280 \\
\end{array}$ & $\begin{array}{c}+ \\
174 \\
\end{array}$ & $\begin{array}{c}+ \\
320 \\
\end{array}$ & $\begin{array}{l}+++ \\
299\end{array}$ & 237 \\
\hline $\begin{array}{l}\text { INDIVIDU } \\
\text { ALS }\end{array}$ & 22 & 23 & 24 & $\begin{array}{l}\text { Control } \\
\text { group }\end{array}$ & 25 & 26 & 27 & 28 & 29 & 30 & 31 \\
\hline Age (years) & 8 & 9 & 10 & $111-20$ & 11 & 11 & 11 & 11 & 12 & 15 & 15 \\
\hline Gender & $\mathrm{F}$ & $\mathrm{F}$ & $\mathrm{F}$ & $\begin{array}{l}\text { Mean of } \\
\text { l1 }\end{array}$ & $\mathrm{F}$ & $\mathrm{F}$ & $\mathrm{F}$ & м & $\mathrm{F}$ & $\mathrm{F}$ & $\mathrm{F}$ \\
\hline Gene & NIPBL & NIPBL & $S M C 1 A$ & $\begin{array}{l}\text { individual } \\
\text { s. }\end{array}$ & $S M C I A$ & NIPBL & NIPBL & & NIPBL & NIPBL & NIPBL \\
\hline Mutation & $\begin{array}{c}c .6860 T->c \\
\text { p.L2287p }\end{array}$ & $\begin{array}{c}\text { c. } 54836>A \\
\text { p.Arg1828G } \\
\text { In }\end{array}$ & & & $\begin{array}{l}\text { c. } 2369 G>A \\
\text { p.Arg790GIn }\end{array}$ & Chr 5p 13.1 & 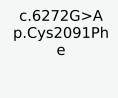 & & c.7928-7929delCA & $\begin{array}{c}\text { c.5467A> } \\
G \\
\text { missense } \\
\text { p.Asn182S } \\
\text { p }\end{array}$ & c.7586A \\
\hline \multirow{2}{*}{$\begin{array}{l}\text { Clinical } \\
\text { Score } \\
\text { GERD } \\
\text { SGD }\end{array}$} & 13 & & 6 & & 14 & 11 & 14 & 15 & 8 & 7 & 11 \\
\hline & $\begin{array}{c}+ \\
166\end{array}$ & ${ }_{254}^{+++}$ & $\begin{array}{l}++ \\
167\end{array}$ & $\begin{array}{l}217.18 \pm 2 \\
9.99\end{array}$ & $\stackrel{+}{162}$ & $\stackrel{+}{144}$ & ${ }_{232}^{+}$ & $\begin{array}{l}++ \\
174\end{array}$ & 172 & 184 & $\begin{array}{l}+++ \\
120\end{array}$ \\
\hline $\begin{array}{l}\text { INDIVIDU } \\
\text { ALS }\end{array}$ & 32 & 33 & 34 & 35 & 36 & 37 & $\begin{array}{c}\text { Control } \\
\text { group }\end{array}$ & 38 & 39 & 40 & 41 \\
\hline $\begin{array}{l}\text { Age (years) } \\
\text { Gender } \\
\text { Gene } \\
\text { Mutation }\end{array}$ & $\begin{array}{c}15 \\
\text { M } \\
\text { NPBL } \\
\text { Mosaicism }\end{array}$ & $\begin{array}{c}16 \\
F \\
?\end{array}$ & $\begin{array}{c}16 \\
F \\
\text { NIPBL } \\
\text { c.6964.695insAT } \\
\prod A \\
\text { p.Ala2325* }\end{array}$ & $\begin{array}{c}16 \\
M \\
N I P B L\end{array}$ & $\begin{array}{c}17 \\
M \\
N / P B L \\
\text { c.6242G->C } \\
\text { p.Gly2081Val }\end{array}$ & $\begin{array}{l}20 \\
F B L \\
\text { NIPBL }\end{array}$ & $\begin{array}{l}21-30 \text { years } \\
\text { Mean of 10 } \\
\text { individuals }\end{array}$ & $\begin{array}{l}21 \\
21 \\
\text { NIPBLI? }\end{array}$ & $\begin{array}{l}22 \\
F \\
S M C 3\end{array}$ & $\begin{array}{c}23 \\
M \\
N / P B \\
\text { Delection }\end{array}$ & $\begin{array}{c}25 \\
F \\
\text { NPBBL } \\
\text { c.3745AZG }\end{array}$ \\
\hline \multirow{2}{*}{$\begin{array}{l}\text { Clinical } \\
\text { Score } \\
\text { GERD } \\
\text { SGD }\end{array}$} & 8 & 9 & 15 & 9 & 14 & 6 & & 16 & 4 & 13 & 7 \\
\hline & ${ }_{76}^{+++}$ & $\stackrel{+}{171}$ & ${ }_{125}^{+++}$ & $\stackrel{+}{126}$ & $\begin{array}{c}+ \\
188\end{array}$ & 209 & $206.40 \pm 22$ & $\begin{array}{l}++ \\
196\end{array}$ & $\stackrel{+}{283}$ & 151 & 192 \\
\hline $\begin{array}{l}\text { INDIVIDU } \\
\text { ALS }\end{array}$ & 42 & 43 & Control group & 44 & 45 & 46 & $\begin{array}{c}\text { Control } \\
\text { group } \\
\end{array}$ & 47 & & & \\
\hline $\begin{array}{l}\text { Age (years) } \\
\text { Gender } \\
\text { Gene } \\
\text { Mutation }\end{array}$ & $\begin{array}{c}25 \\
\begin{array}{c}25 \\
\text { NIPBL }\end{array}\end{array}$ & $\begin{array}{l}26 \\
\text { F } \\
?\end{array}$ & $\begin{array}{l}\text { 31-40 years } \\
\text { Mean of } 8 \\
\text { individuals }\end{array}$ & $\begin{array}{c}32 \\
F \\
\text { NIPBL }\end{array}$ & $\begin{array}{c}34 \\
\text { M } \\
\text { NIPBL mosaicism }\end{array}$ & $\begin{array}{c}37 \\
F \\
\text { NIPBL } \\
\text { c.5471CT } \\
\text { p.Ser1824Leu }\end{array}$ & $\begin{array}{l}\text { 41-50 years } \\
\text { Mean of } 8 \\
\text { individuals }\end{array}$ & $\begin{array}{l}42 \\
\text { M } \\
\text { NIPBL }\end{array}$ & & & \\
\hline \multirow{2}{*}{$\begin{array}{l}\text { Clinical } \\
\text { Score } \\
\text { GERD } \\
\text { SGD }\end{array}$} & 10 & 11 & & 15 & 16 & 13 & & 13 & & & \\
\hline & ${ }_{74}^{+++}$ & 273 & $215.28 \pm 31.40$ & $\begin{array}{c}+ \\
127\end{array}$ & 174 & 159 & $202.50 \pm 22$ & ${ }_{94}^{+++}$ & & & \\
\hline
\end{tabular}

Individuals are differentiated in decades of life by different shading colours from: white: 1st decade of life; light grey: 2nd decade of life; medium grey: 3rd decade of life; grey: 4th decade of life; dark grey: 5 th decade of life. $M$ male, $F$ female, PNS Peripheral Nervous System, GERD Gastroesophageal reflux disease ($\mathrm{no},+$ mild, + + moderate, + + + severe), SGD Sweat Gland Density: gland number $/ \mathrm{cm}^{2}$

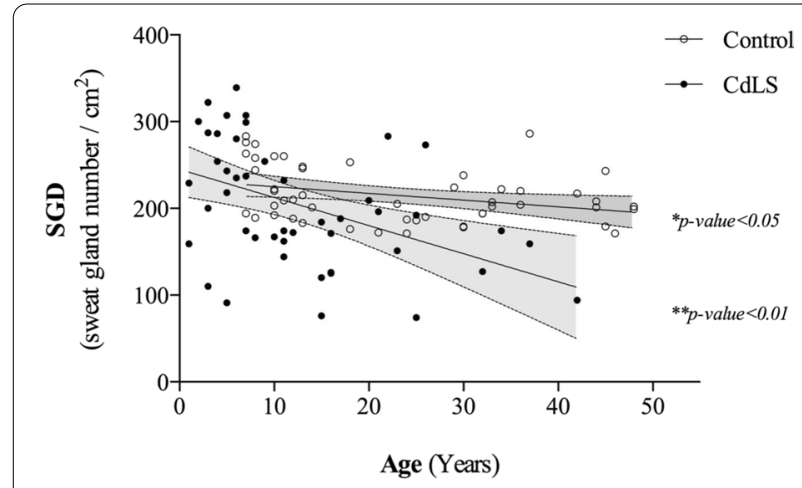

Fig. 2 Analysis of SGD. (SGD: sweat gland density: gland number/ $\mathrm{cm}^{2}$ ): each dot corresponds to a different individual at the indicated age. Filled dots are CdLS individuals $(n=47)$ and empty dots correspond to control individuals $(n=50)$. Lines show mean linear fit and $95 \%$ confidence intervals (shadowed areas). Significant non-zero slope, linear regression, ${ }^{*} p$-value $<0.05,{ }^{* *} p$-value $<0.01$
Table 4 SGD by decades of life

\begin{tabular}{llllll}
\hline & Controls & N & CdLS NIPBL & N & $\mathbf{p}^{\mathbf{a}}$ \\
\hline Mean SGD $\left(\mathrm{g} / \mathrm{cm}^{2}\right) \pm S D$ & $217.60 \pm 30.61$ & 50 & $178.03 \pm 72.53$ & 27 & 0.001 \\
$\begin{array}{l}\text { Mean SGD }\left(\mathrm{g} / \mathrm{cm}^{2}\right) \pm S D \\
\text { by decades of life }\end{array}$ & Controls & $\mathrm{N}$ & CdLS NIPBL & $\mathrm{N}$ & $\mathrm{p}^{\mathbf{a}}$ \\
$\leq 10$ years & $236.76 \pm 34.81$ & 13 & $226.00 \pm 86.60$ & 10 & 0.686 \\
$11-20$ years & $217.18 \pm 29.99$ & 11 & $159.09 \pm 45.35$ & 11 & 0.002 \\
21-30 years & $206.40 \pm 22.9$ & 10 & $139.00 \pm 59.90$ & 3 & 0.010 \\
31-40 years & $215.28 \pm 32.40$ & 8 & $143.00 \pm 22.62$ & 2 & 0.013 \\
$41-50$ years & $202.50 \pm 22.16$ & 8 & 94.0 & 1 & 0.002
\end{tabular}

Values for sweat gland density in CdLS individuals with variants in NIPBL and controls by groups of age

a Independent samples $t$ test. There are statistically significant differences $(p<0.05)$ in the SGD global mean (control group compared to the global NIPBL group) and by decades of life, in all the decades except in the first one 
mutation, a frameshift mutation in 2 siblings. According to the asymmetry in the SSR response, 3 of the NIPBL individuals had missense mutations, 2 of them frameshift mutations and 1 of them splicing mutation, but the number of individuals is not big enough to do a correlation with the autonomic neuropathy. Further studies are warranted to look at autonomic nervous system dysfunction and relation to mutated gene and age in individuals with CdLS.

\section{Conclusion}

Individuals with CdLS have abnormal autonomic nervous system function, showing asymmetries in the sympathetic responses in lower limbs, and pathological results in the sudomotor test. The degree of dysfunction in postganglionic sudomotor nerve fibers might be related to premature aging. Even though, somatic nervous system function studies were normal.

\section{Abbreviations}

CdLS: Cornelia de Lange Syndrome; PNS: Peripheral nervous system; SGD: Sweat gland density; GERD: Gastroesophageal reflux disease; CSS: Clinical severity score.

\section{Supplementary Information}

The online version contains supplementary material available at https://doi. org/10.1186/s13023-021-02082-y.

Additional file 1. Tables 1 to 4: Motor and Sensory Nerve Conduction Studies Parameters.

\section{Acknowledgements}

We thank the families who participated in this study.

\section{Authors' contributions}

Conceptualization, M.J.P., F.R., J.P., and B.P.; nerve conduction studies, P.P., M.H.; autonomic nervous system studies, M.J.P., I.B., L.M.K.; clinical studies, F.R., G.B.L., L.T., F.J.K., S.A.H. and A.D.K.; genetics, A.L.P., M.A., S.A.H. and F.J.K.; writing-original draft preparation, M.J.P., J.P. and B.P.; writing - review, L.M.K., S.A.H., F.J.K., F.R., A.D.K., J.P. and B.P.; writing-editing, M.J.P., P.P., M.H., I.B., A.L.P., M.A., L.T., G.B.L., L.M.K., S.A.H., F.J.K., F.R., A.D.K., J.P. and B.P. All authors have read and agreed to the published version of the manuscript.

\section{Funding}

This work is supported by the FIS, Fundación de Investigación Sanitaria, Spain [Ref.\# PI19/01860, to F.R. and J.P.] and the DGA (Diputación General de Aragón)_FEDER (Federación de Enfermedades Raras): European Social Fund (Group: B32_17R, to J.P.).

\section{Availability of data and materials}

The authors confirm that the data supporting the findings of this study are available within the article and its supplementary materials.

\section{Declarations}

Ethics approval and consent to participate

The protocol study was approved by the Ethics Committee of Clinical Research from the Government of Aragón (CEICA; PI16/225). All the individuals with $\mathrm{CdLS}$ and controls gave informed consent for their participation.

\section{Consent for publication}

All the individuals with CdLS and controls gave informed consent for the publication of this work.

\section{Competing interests}

The authors declare that they have no competing interests.

\section{Author details}

${ }^{1}$ Unit of Clinical Genetics and Functional Genomics, Department of Pharmacology-Physiology, School of Medicine, University of Zaragoza, CIBERER-GCV02 and IIS-Aragon, Zaragoza, Spain. ${ }^{2}$ Unit of Neurophysiology, San Jorge University Hospital, Huesca, Spain. ${ }^{3}$ Unit of Neurophysiology, Miguel Servet University Hospital, Zaragoza, Spain. ${ }^{4}$ Unit of Clinical Genetics, Department of Pediatrics, Hospital Clinico Universitario "Lozano Blesa", CIBERER-GCV02 and IIS-Aragon, Zaragoza, Spain. ${ }^{5}$ Department of Pediatrics, Hospital Clinico Universitario "Lozano Blesa", Growth, Exercise, Nutrition and Development (GENUD) Research Group, Zaragoza, Spain. ${ }^{6}$ Division of Pediatric Neurology, Department of Paediatrics, University of Utah Health, Salt Lake City, UT, USA. ${ }^{7}$ Department of Pediatrics, Amsterdam UMC, Amsterdam, The Netherlands. ${ }^{8}$ Prinsenstichting, Purmerend, The Netherlands. ${ }^{9}$ Institute of Human Genetics, University Hospital Essen University of Duisburg-Essen, Essen, Germany. ${ }^{10} \mathrm{Har}$ vey Institute of Human Genetics, Greater Baltimore Medical Center, Baltimore, MD, USA.

Received: 17 May 2021 Accepted: 10 October 2021

Published online: 30 October 2021

\section{References}

1. Kline AD, Moss JF, Selicorni A, Bisgaard AM, Deardorff MA, Gillett PM, Ishman SL, Kerr LM, Levin AV, Mulder PA, Ramos FJ, Wierzba J, Ajmone PF, Axtell D, Blagowidow N, Cereda A, Costantino A, Cormier-Daire V, FitzPatrick D, Grados M, Groves L, Guthrie W, Huisman S, Kaiser FJ, Koekkoek G, Levis M, Mariani M, McCleery JP, Menke LA, Metrena A, O'Connor J, Oliver C, Pie J, Piening S, Potter CJ, Quaglio AL, Redeker E, Richman D, Rigamonti C, Shi A, Tümer Z, Van Balkom IDC, Hennekam RC. Diagnosis and management of Cornelia de Lange syndrome: first international consensus statement. Nat Rev Genet. 2018;19(10):649-66.

2. Pié J, Gil-Rodríguez MC, Ciero M, López-Viñas E, Ribate MP, Arnedo M, Deardorff MA, Puisac B, Legarreta J, de Karam JC, Rubio E, Bueno I, Baldellou A, Calvo MT, Casals N, Olivares JL, Losada A, Hegardt FG, Krantz ID, Gómez-Puertas P, Ramos FJ. Mutations and variants in the cohesion factor genes NIPBL, SMC1A, and SMC3 in a cohort of 30 unrelated patients with Cornelia de Lange syndrome. Am J Med Genet A. 2010;152A(4):924-9. https://doi.org/10.1002/ajmg.a.33348.

3. Teresa-Rodrigo ME, Eckhold J, Puisac B, Dalski A, Gil-Rodríguez MC, Braunholz D, Baquero C, Hernández-Marcos M, de Karam JC, Ciero M, Santos-Simarro F, Lapunzina P, Wierzba J, Casale CH, Ramos FJ, GillessenKaesbach G, Kaiser FJ, Pié J. Functional characterization of NIPBL physiological splice variants and eight splicing mutations in patients with Cornelia de Lange syndrome. Int J Mol Sci. 2014;15:10350-64.

4. Ramos FJ, Puisac B, Baquero-Montoya C, Gil-Rodríguez MC, Bueno I, Deardorff MA, Hennekam RC, Kaiser FJ, Krantz ID, Musio A, Selicorni A, FitzPatrick DR, Pié J. Clinical utility gene card for: Cornelia de Lange syndrome. Eur J Hum Genet. 2015. https://doi.org/10.1038/ejhg.2014.270.

5. Gil-Rodríguez MC, Deardorff MA, Ansari M, Tan CA, Parenti I, BaqueroMontoya C, Ousager LB, Puisac B, Hernández-Marcos M, Teresa-Rodrigo ME, Marcos-Alcalde I, Wesselink JJ, Lusa-Bernal S, Bijlsma EK, Braunholz D, Bueno-Martinez I, Clark D, Cooper NS, Curry CJ, Fisher R, Fryer A, Ganesh J, Gervasini C, Gillessen-Kaesbach G, Guo Y, Hakonarson H, Hopkin RJ, Kaur M, Keating BJ, Kibaek M, Kinning E, Kleefstra T, Kline AD, Kuchinskaya E, Larizza L, Li YR, Liu X, Mariani M, Picker JD, Pié A, Pozojevic J, Queralt E, Richer J, Roeder E, Sinha A, Scott RH, So J, Wusik KA, Wilson L, Zhang J, Gómez-Puertas P, Casale CH, Ström L, Selicorni A, Ramos FJ, Jackson LG, Krantz ID, Das S, Hennekam RC, Kaiser FJ, FitzPatrick DR, Pié J. De novo heterozygous mutations in SMC3 cause a range of Cornelia de Lange syndrome-overlapping phenotypes. Hum Mutat. 2015;36(4):454-62. https://doi.org/10.1002/humu.22761.

6. Huisman S, Mulder PA, Redeker E, et al. Phenotypes and genotypes in individuals with SMC1A variants. Am J Med Genet A. 2017;173(8):2108-25. 
7. Parenti I, Gervasini C, Pozojevic J, et al. Expanding the clinical spectrum of the 'HDAC8-phenotype'-implications for molecular diagnostics, counseling and risk prediction. Clin Genet. 2016;89(5):564-73.

8. Cucco F, Sarogni P, Rossato S, Alpa M, Patimo A, Latorre A, Magnani C, Puisac B, Ramos FJ, Pié J, Musio A. Pathogenic variants in EP300 and ANKRD11 in patients with phenotypes overlapping Cornelia de Lange syndrome. Am J Med Genet A. 2020;182(7):1690-6. https://doi.org/10. 1002/ajmg.a.61611.

9. Parenti I, Diab F, Gil SR, Mulugeta E, Casa V, Berutti R, Brouwer RWW, Dupé V, Eckhold J, Graf E, Puisac B, Ramos F, Schwarzmayr T, Gines MM, van Staveren T, van IJcken WFJ, Strom TM, Pié J, Watrin E, Kaiser FJ, Wendt KS. MAU2 and NIPBL Variants impair the heterodimerization of the cohesin loader subunits and cause Cornelia de Lange Syndrome. Cell Rep. 2020;31(7):107647. https://doi.org/10.1016/j.celrep.2020.107647.

10. Kerr LM, Jones A, Kline AD, Fischer PR. Compass-31 questionnaire screening in individuals with Cornelia de Lange syndrome. Am J Med Genet A. 2017;173(5):1172-85.

11. Recommendations for the Practice of Clinical Neurophysiology. Guidelines of the International Federation of Clinical Neurophysiology. New York: Elsevier; 1999

12. Kimura J. Electrodiagnosis in diseases of nerve and muscle. Principles and Practice. Fourth Edition. New York: Oxford University Press; 2013.

13. Ryan CS, Conlee EM, Sharma R, Sorenson EJ, Boon AJ, Laughlin RS. Nerve conduction normal values for electrodiagnosis in pediatric patients. Muscle Nerve. 2019;60(2):155-60.
14. Hylienmark L, Ludvigsson J, Brismar T. Normal values of nerve conduction studies in children and adolescents. Electroencephalogr Clin Neurophysiol. 1995;97(5):208-14

15. Tekgül H, Polat M, Tosun A, Serdaroğlu G, Gökben S. Electrophysiologic assessment of spasticity in children using H-reflex. Turk J Pediatr. 2013;55:519-23.

16. Ziegler D, Laux G, Dannehl K, Spüler M, Mühlen H, Mayer P, Gries FA. Assessment of cardiovascular autonomic function: age-related normal ranges and reproducibility of spectral analysis, vector analysis, and standard tests of heart rate variation and blood pressure responses. Diabet Med. 1992;9:166-75.

17. Akyuz G, Turkdogan-Sozuer D, Turan B, Canbolat N, Yilmaz I, Us O, Kayhan O. Normative data sympathetic skin response and RR interval variation in Turkish children. Brain Dev 21:99-102.

18. Uncini A, Pullman SL, Lovelace RE, Gambi D. The sympathetic skin response normal values, elucidation of afferent components. J Neurol Sci. 1988;87:299-306.

19. Ferrer T, Ramos MJ, Pérez-Jiménez A, Pérez-Sales P, Álvarez E. Sympathetic sudomotor function and aging. Muscle Nerve. 1995;18(4):395-401.

\section{Publisher's Note}

Springer Nature remains neutral with regard to jurisdictional claims in published maps and institutional affiliations.
Ready to submit your research? Choose BMC and benefit from:

- fast, convenient online submission

- thorough peer review by experienced researchers in your field

- rapid publication on acceptance

- support for research data, including large and complex data types

- gold Open Access which fosters wider collaboration and increased citations

- maximum visibility for your research: over $100 \mathrm{M}$ website views per year

At BMC, research is always in progress.

Learn more biomedcentral.com/submissions 